\title{
A Leacockian View Of Economics Today
}

\author{
SREenivasan Subramanian* \\ Retired Professor of Economics from Chennai, India \\ ssubramanianecon@gmail.com \\ March 13, 2017
}

\begin{abstract}
Stephen Leacock published a book called Nonsense Novels in 1911. Drawing mainly on the stories in that volume (and indeed employing the same titles), and also on some other of Leacock's writings, the ensuing offerings are a re-telling of the Leacock pieces employing themes in economics and economics-related matters. It is worth recalling that Leacock himself was an economist, being, in real life, Professor of Political Economy at McGill University, Canada. The excuse for the present set of imitations of imitations is that the author, like Leacock, was also a professor of Economics who had to retire for reasons of growing old but not (just as in Leacock's case) for reasons of growing up: as Leacock said in his Preface to his Nonsense Novels, 'The reviewers...were good enough to express the thought that when the author grew up and became educated there might be hope for his intellect. This expectation is of no avail. All that education could do in this case has been tried and has failed. As a Professor of Political Economy..., the author admits that he ought to know better.' So ought the present writer, but what contributed to Leacock's Literary Lapses (if not to his Political Economy) should be bad enough to contribute to the present writer's own lapses, too.
\end{abstract}

\section{MAdDEnED By MYstery}

It was on a wild and wintry evening of the year '15, I find recorded in my notebook, that the world first became acquainted with that chain of singular circumstances which led to the arrival, in the drawing room of our humble quarters, of an entity that at first sight appeared to be a drone but turned out, when once the disguise had been penetrated, to be, instead, the President of the United States of America, who found my friend swathed in a mouse-coloured dressing gown, his eyes concealed behind a pair of violet goggles, his upper lip adorned by a luxurious red false moustache, and his head wreathed in clouds of smoke from a Meerschaum filled with shag stuffed from a Persian slipper.

*The second item in this essay ('The Conjurer's Revenge') appeared earlier in the Economic and Political Weekly (50:45, November 7, 2015), written under the author's pseudonym of 'Toothcomber'. 
"Pray take a seat," said the Great Detective, "and let me know, in your own words, while omitting no detail, however slight, what has fetched you from the city of Washington in the District of Columbia to Baker Street in the city of London."

The President gave a violent start. "How do you know I'm from Wash_??" he began, when he was cut short impatiently by the Great Man:

"Tut, man, your boarding pass is sticking out of your pocket, apart from which those ears, made familiar to the point of despair by photographs in the daily newspapers, are too prominent to mistake. The case now, if you will."

"I have not the time to tarry," said the President, "busy as I am, conducting drone attacks on the civilian population with very occasional collateral damage to the real targets. Suffice to say that a neo-Keynesian who has been strenuously recommending a stimulus package for the economy has been found strenuously murdered in his study."

"Are the police," asked the Great Detective, "and the CIA and the FBI baffled beyond endurance? Does the case have international ramifications beyond imagination? If unsolved, will the case trigger World War III in the next 19-and-a-half hours? Does it involve some of the most distinguished names in America, Europe and the rest of the world, or at least some of the less distinguished names? Do you have anything to add?

"In response to your first four queries," replied the President, "Yes, yes, yes, and yes. In response to your fifth query, my Intelligence sources advise me that the list of suspects has been narrowed down, for reasons we need not get into now, to three persons: a Syrian terrorist, the former President of the U.S., and a Professor of Economics at Chicago University. Your travel has been arranged, and I will be personally indebted to you if you should take the next flight to D.C. and investigate the case."

"Very well," said the Great Detective, adding, as he turned to me, "Pray pack a valise containing a few false beards, three pairs of goggles, twenty-three dressing gowns, my magnifying glass, the chemistry kit, a knife to skewer my correspondence with, a gasogene, a decanter, an Inverness cape, a deer-stalker, and some dog-biscuits for yourself."

In some hours, the Great Detective and I were in Washington, D. C. Upon his asking, the Great Detective was led to the murder victim's body in the mortuary. The Great Detective put on his deer-stalker, he affixed a green moustache to his upper-lip, and with the additional disguise of a red clown's nose, he threw himself upon the ground, sniffed the air, and crawled, on all fours, to the body, which he submitted to minute examination through the wrong end of his microscope. "Ha!" he said, his eyebrows waggling, his nose quivering, and his voice quavering, "Ha! Ho! Hum! Ha-ha!"

Suddenly, he flung himself up and unwinding his long, thin frame while simultaneously helping himself to a maroon moustache and a pair of pink glasses, he said: "That was a pretty three-pipe problem which I have succeeded in addressing with a single Meerschaum. The case is solved."

"My dear fellow! Who did it?"

"Obviously not the Syrian terrorist, since he has a perfect alibi by virtue of having 
been in Syria at the time of the murder. Observe the marks on the body, which clearly indicate that the victim has been murdered by first differentiating and equating to zero, and then differentiating again and confirming negativity. The murder, obviously, has been perpetrated by a utility-maximizer, punctilious in the employment of both firstand second-order conditions for an extremum. We can immediately rule out the former President as a potential suspect: he can hardly be credited with engaging in the differential calculus when he has difficulty adding and spelling. Who, then, given to fanatical utilitymaximization, might be expected to do violence to a neo-Keynesian economist, if not a Professor of Economics from Chicago? Hold him, before he escapes_.!"

Unnoticed, the Chicago Economics Professor had followed us into the mortuary, but Inspector Lestrade (who had accompanied us from London) was too quick for him. "Would you?" he snarled, attaching himself to the sullen Professor's collar, as the latter tried to sneak away quietly.

Back in the White House, the Great Detective had the Presidential Medal pinned to his breast. He was also quickly conferred Membership of the American Academy of Arts and Sciences, and granted both the Oscar and Emmy Awards. "Is there," enquired the President, "anything further we can do to honour you? A special edition of American Idol, perhaps? A Hollywood extravaganza, maybe?"

"Tut, man," said the Great Detective carelessly. "The work is its own reward," and, turning to me, "If I may trouble you now for the syringe bearing a bolus of the good old seven per cent solution, followed by the papers of the Fotherington-Cholomondoley Succession Case and then the Featherstonehaugh-Beauchamp Forgery Case_.? Ah, thank you."

\section{The Conjurer's Revenge}

The audience had assembled to witness the Great Poverty Escape Act, conceived, sponsored, funded and executed by the Global Magical Moneylenders' Guild of Reconstruction and Dissimulation under the inspiring leadership of the Great Conjurer, whose official designation was that of Head of the Research Committee of the Department of Mysteries in the Ministry of Magic ( with registered country offices in the world-wide branches of the Hogwarts School of Witchcraft and Wizardry), aided by the services of the International Stooges' Federation of Hand-Waving Economeretricians ${ }^{1}$.

"Now, ladies and gentlemen," said the Great Conjurer, "I shall produce very little out of a great deal - 902 million poor people in 2012 out of 1959 million poor people in 1980. We are ahead of schedule in meeting Millennium Development Goal 1. Presto!"

People everywhere in the audience were saying, "Oh, how marvelous! How did he do it?"

\footnotetext{
${ }^{1}$ Martin Gardner is rumoured to have been present at the Federation's naming ceremony
} 
But the Quick Man on the front seat flung himself on his favourite idea and whispered madly in all directions: "He - had - a - particularly - low - poverty - line - up - his - sleeve." And the people in the audience nodded sagely and sent the whisper flying to every corner of the hall: "He - had - an - extra-small - poverty - line - up - his - sleeve."

"My next trick," said the Great Conjurer "is the famous Hindostanee Vanishing Numbers Trick. I shall now cut the Indian poverty headcount ratio by a further 20 per cent. Choo mantar! Also Presto!"

The audience reacted dazedly to this bold decapitation, until the Quick Man whispered: "He - had - a - sub-Tendulkar-Committee - Poverty - Line - up - his - sleeve." And everybody agreed and whispered: "Yes - he - had - a - sub-Tendulkar-Committee Poverty - Line - up - his - sleeve."

The Great Conjurer's Olympian brow developed a furrow or two or three, as he continued: "I shall now amuse and entertain and gratify you with the Modified Hindostanee Vanishing Numbers Trick whereby I shall cut the Indian headcount ratio by an even more daring 10 per cent. Will one of the obliging Economeretricians kindly lend me his wand? Ah - thank you - Presto!"

He cut the headcount ratio by a further 10 per cent, one per cent at a time, and for thirty-five seconds the audience was spell-bound, until the Quick Man whispered: "He had - a - Modified - Mixed - Recall - Period - up - his - sleeve," and all the people in the audience passed it on: "He - had - a - Modified - Mixed - Recall - Period - up - his - sleeve."

The headcount trick was ruined.

Through the show, it went on like that. It transpired from the whispers of the Quick Man that the Great Conjurer must have had hidden up his sleeve, apart from a minuscule global poverty line, a sub-Tendulkar-Committee Poverty Line and a Modified Mixed Recall Period, also stacks and stacks of bogus Purchasing Power Parity equivalences, an entire Calorie Drift, several scores of country-specific Poverty Thresholds of which only the lowest 15 were used, a live (or at least only semi-moribund) poverty expert, an inventory of spurious regressions, hundreds of consumer price indices that failed to measure inflation, a Mainframe Super Computer capable of delivering a thousand doctored aggregate headcounts per second-squared, a full band for musical side-effects, a troop of cheer-leaders, a copy of Harry Frankfurt's On Bullshit, and a crammer's guide to Advanced Economicstricks.

The Great Conjurer's and the Federation's reputations were in tatters. At the end of the show, the Great Conjurer made a final effort to salvage what he could of the evening.

"Ladies and gentleman," he said, "I will now conclude the evening's entertainment with the celebrated Icelandic trick invented long ago by India's tantric votaries of kundalini, whereby," turning to the Quick Man with a smile of chillingly suave savagery, "I shall now, with this gentleman's permission, do indescribable things to his collar, his hat, his watch and his coat. If I may, sir?" 
"Of course you may," said the Quick Man with an affable smile, "but I can save everybody a lot of time and bother by confidently asserting that you will have done those indescribable things with the help of a cigarette lighter, a pair of gardening shears, a pair of dancing shoes and a pot of green paint hidden - up - your - sleeve."

And once more the whisper went round the hall: "He - has - all - those - things - up - his - sleeve."

Amid a burst of dispirited music from the orchestra, the curtain descended upon the evening's edification, and the audience dispersed, convinced that there is not a trick in the book, especially when it comes to performing a Houdini Act on Global Poverty, which is not done up the Great Conjurer's sleeve.

\section{3 “Q." A Psychic Pstory of the Psupernatural}

What I am about to relate is the true but incredulous, by which I mean incredible, experience I had of phantasmal phinancial phlows in the ghastly gothic globalized world of ghostly go-betweens operating from beyond the grave. (These are examples of alluring alliterations, but that is another matter, whereas we are here concerned with the immaterial or spirit world, also known as the non-corporeal realm of miasmic manifestations, or perhaps something else.) Let me begin at the beginning, passing up the temptation of starting earlier. It began with my meeting $\mathrm{A}$, on his invitation, in his chambers, at 4:52 P.M. precisely, on December the 23rd, a date and time which are graven in my memory if for no other reason than that I am not forgetful, either by nature or by design, assuming that means anything. A was a precise, unemotional, dry-voiced, dry-faced, drip-dried individual who worked in some mysterious import-export business that dealt, as far as one could tell, with things that were Free on Board or involved Cost, Insurance and Freight, Bills of Lading and Letters of Credit. One would have scarcely associated this seemingly unimaginative and unsentimental man with astral phenomena or preternaturally paranormal events - with, in a word - ghosts, but then there we are.

In a quiet and even voice, A told me that his old, late friend (or late, old friend) Q, who had passed on (by which I mean expired) some years ago, seemed to be making an effort to get in touch with him, A, from the spirit world. "Addicted as Q had been to the world of shady transactions and tax havens all his adult corporeal life," A opined, "his premature death left in its wake a restless unsatiated spirit that would not rest quiescent in the knowledge of its unrealized potentialities for advancing the cause of illicit financial flows. I have been given an imitation, or intimation, of A's desire to get in touch with me. My attention was drawn from the reverie on illegal discounted cash flows into which I had fallen while sitting at my desk the other evening, by the sound of three sharp raps, as upon the table. Like this," added A, rapping the wooden desk sharply and causing me to bite my tongue and jump out of my skin. Re-entering my skin, I heard A relate the following singular tale: 
"By projecting himself through the ouija board of a psychic medium, Q was able to communicate with me. I could hear him tell me distinctly enough, through the crackling static of the nether world, the following: 'If you will arrange for my friend $\mathrm{X}$ to receive a million units of local currency, I will arrange, through the good offices of $\mathrm{Z}$, to have the equivalent foreign exchange (at a premium, of course) in dollars transferred to a numbered account in Delaware, from where it will be distributed amongst several other numbered accounts, opened in the names of shell companies, in various banks in the Caymen Islands, the Channel Islands, the Isle of Man, Mauritius, the Guernsey and the Channel Islands and Switzerland, all proxying for you, of course, my dear fellow. The funds can be repatriated, in a round-tripping arrangement, by way of bogus foreign investment. Just find those million units of local currency, and you will be in business.' The problem, of course, is that I am not a millionaire, whereas you are. How about it? Will you invest a million local currency units, at no risk to yourself and with the prospect of a premium-bearing foreign exchange return in the bargain, in the cause of advancing the frontiers of knowledge and experience beyond this constraining world of mere material possessions to the world of the spirit and the Great Beyond?"

For a moment I was spell-bound; for another moment, dumb-struck; and for a third moment, tongue-tied. Taking just one more moment off for speechlessness, I recovered my wits and my voice. "Why, of course I will," I replied. "It would be a pleasure to participate in this great scientific experiment!"

"Well then, meet me again with a million smackers tomorrow, same place, same time. Only, the transaction must be conducted entirely in cash." A lowered his voice as he said in a tone of affectionate recollection: "Q always dealt only in cash, and we don't want his sensitive spirit to be offended by negotiations through cheques, do we?"

"No, of course not," I said, in sympathetic identification.

Next day, I passed on a million notes in cash to A. I did not, of course, understand a word of what A said, about Delaware and the Caymen Islands and numbered accounts and shell companies and round-tripping and foreign portfolio investment, but I gathered it was all in the cause of science and an alternative reality in the World Beyond. I was repeatedly struck by the strange and eerie significance of Q getting in touch with A to get in touch with me on the third day of every month of the subsequent six months, with the request, on each occasion, to come prepared to part with a million notes in cash, now for under-invoicing exports, now for over-invoicing imports, now for a spot of transfer-pricing, now for a dash of what $A$ in a sepulchral voice said was financing trade in narcotics, and now again for a round of investment in human trafficking. As I have said, I had no notion of what all these financial transactions meant, except that they were part of this awesome experiment in establishing an ethereal reality, an experiment of which I was proud to be a part.

The culminating mystery occurred at the end of the sixth month. A vanished, as it were, into thin air, leaving no trace of his whereabouts (or of course of my millions). I was 
convinced that he had been sucked up in an osmotic force and into the void of the great spirit world, to be united once more and forever with his great friend Q. I was correct in my speculation. A few days hence I received a confirmatory telephone call. I heard A's voice, as if emanating from the pits of the alien world, assuring me that he was now with $\mathrm{Q}$ in another country of the spirit. He counseled me not to mourn my lost millions, for it had all been in a great and wonderful cause. I was then, and continue to remain, convinced that A was a martyr to the experiment he had conducted with such courage and steadfastness, and that my experience was but a testament to his commitment to the truth.

After all, and as he assured me, my millions were but a paltry fraction of the twenty-five trillion dollars that had escaped the developing world in illicit financial flows.

\section{A Hero in Homespun: or, The Life Struggle of Hezekiah HAYLOFT}

The Chairman of the Department also occupied the Chair of Advanced Mathematical Economics and Economic Theory. It was on this Chair that he was sitting when a freshfaced lad entered his study. It was Hezekiah Hayloft. Hezekiah was entirely in homespun. Hezekiah also carried a carpet-bag in each hand, and the notion in his head that it was a good idea to come to New York in search of an education that would make him an economist capable of understanding and solving the problems of poverty and inequality and unemployment and inflation. He asked the Chairman if he might register for a $\mathrm{Ph}$. D. under him. The Chairman found something engaging in the lad's wistful expression. It might almost be said that he saw his own younger self of long ago in the person standing before him. He threw an ink-pot at him, and him out of the study.

Wandering down the corridor, Hezekiah encountered the college Chaplain and enquired if he, the Chaplain, would pray for him, Hezekiah, to find a berth in the Department to do research on social security for the poor. The Chaplain, in a voice inarticulate with rage, said something about how the wretched lad would be better off studying the properties of unstable equilibria in epsilon environments, but seeing that he was incapable, the Chaplain said that what was indicated was not so much prayer as a good hiding and, suiting the action to the word, he set violently upon Hezekiah and beat the stuffing out of him.

The Chaplain, in his old age, was less thorough than he had been in his youth. He hated to leave a job half done. He entrusted the completion of the commission to the janitor. The janitor was happy to suck Hezekiah up in his vacuum cleaner and then spit him out.

Dejected but not defeated, Hezekiah wandered further down the corridor and buttonholed one of the three Nobel laureates the Department boasted. Expressing a desire to study the importance of the minimum wage for worker welfare, he was confronted by the 
query, addressed in a voice of thunder by the laureate, whether Hezekiah could handle Haufsdorff dimensions and Banach spaces in the cause of demonstrating the uniqueness of stable steady states in the core of a competitive economy yielded by the non-degenerate intersection of $n$-manifolds. Hezekiah answered truthfully: "I can often add with varying success, occasionally subtract, and more rarely do a sum in long division. But I am prepared to work hard and learn." The laureate, thereupon, chewed off his ear, kicked him several times in the hind-quarters, and sent him on his way - but not before he had arranged for Hezekiah to run the gauntlet of the Department's 21 graduate students of whom three were female all-in wrestlers specializing in subgame perfect coalition proof Nash equilibria.

Gradually, with the passage of time and repeated exposure to insults, kicks, bites, dusters and ink-pots, a change came over the lad: he became embittered and hardened. Thrusting his substantial jaw out, he muttered to himself: "I will succeed yet, by foul means if not fair; yes I will - by Jupiter, by Friedman, by Barro, by Muth!" So saying, he systematically broke into the rooms of the senior faculty and stole all the results of their work in progress.

Before he knew it, Hezekiah was in possession of 132 lemmata and 193 theorems on the super-neutrality of money, the inefficacy of fiscal stimulus, the efficacy of macroeconomic stabilization and structural adjustment, the necessity of debt-recovery by force and violence, the hyper-optimality of unfair trade practices, the multidimensional nature of lies about global poverty, and the incentive-compatible uniqueness of growth equilibria without foreign aid. What is more, he boldly published his stolen results in the most prestigious journals of the day. He was hired by several supra-national institutions such as the Global Bank, the International Trade Organization, and the World Monetary Fund to destroy several developing economies, which he did. His success knew no bounds. His reputation grew and grew. It was only a matter of time before he was offered permanent tenure in the Departments of several Ivy League Colleges, which vied desperately with each other to hire him, and bid his remuneration up in the bargain. The very men who had sneered at him now groveled at his feet. It was Hezekiah who now brandished the ink-pots.

To keep his reputation going, Hezekiah had to hire several research assistants and graduate students, from all of whom he stole his ideas and his scientific papers. When one of the students delayed the proof of a lemma, Hezekiah shot him through the waistcoat. He came to stand his trial in court. The prosecuting attorney, the witnesses, the judge, the jury and the press were all very sympathetic to Hezekiah. The court found in his favour and awarded him damages. However, the verdict was challenged in the Supreme Court on a writ of mandamus, followed by a writ of certiori. There the case now stands, at the end of twenty-three years and 1,912 adjournments.

Meanwhile, Hezekiah was appointed President of Halfward University whose funds he speculated with for his private gain and which he sensibly invested in the cause of his election to the State Senate. 
Hezekiah Hayloft's life struggle will soon culminate with his election as President of the country.

\section{THE END}

